\title{
Pengaruh Persepsi Anggota, Kepercayaan Nasabah dan Anggaran Partisipatif terhadap Kinerja Manajerial Melalui Kepuasan Kerja Pada Baitul Maal Wat Tamwil "X" Kota Padang
}

\author{
Yenni Del Rosa*, Muhammad Abdilla \\ Universitas Dharma Andalas \\ *Correspondence email: yennidelrosa62@gmail.com, m.abdilla@yahoo.co.id
}

\begin{abstract}
This study aims to determine the effect of member perceptions, customer trust and participatory budgets on managerial performance through moderating job satisfaction in Baitul Maal wat Tamwil (BMT) "X" Padang city. This type of research includes quantitative types in the form of primary data collected by questionnaire, population and 25 research samples were taken using the census method Data analysis techniques used Structural Equations Model (path analysis) The results showed that managerial performance was explained directly by member perceptions, customer trust and participatory budgets through job satisfaction in BMT " $X$ " cities The perception of members moderates the relationship of job satisfaction with managerial performance in BMT " $X$ " Padang city. Customer trust does not moderate the relationship of job satisfaction with managerial performance in BMT " $X$ " Padang city. Participatory budgets do not moderate the relationship of job satisfaction with managerial performance in $B M T$ " $X$ "Padang city.
\end{abstract}

Keywords: member perceptions; customer trust; participatory budgeting; job satisfaction and managerial performance

\section{PENDAHULUAN}

Baitul Maal wat Tamwil (BMT) sebagai Lembaga Keuangan Mikro (LKM) melakukan kegiatan penyediaan jasa keuangan bagi pengusaha kecil dan mikro untuk masyarakat berpenghasilan rendah yang tidak terlayani oleh lembaga keuangan formal berorientasi untuk tujuan bisnis. Menurut (Buchori, 2003) LKM menyediakan jasa keuangan mikro dengan tujuan utama untuk pengembangan masyarakat (Buchori, 2003). Pemberian pinjaman untuk usaha kecil dan mikro mempunyai tujuan utama sbb: 1) Menciptakan lapangan kerja melalui penciptaan dan pengembangan usaha mikro, 2) Meningkatkan produktivitas dan pendapatan kelompok yang rentan terutama perempuan dan orang miskin, 3) Mengurangi ketergantungan masyarakat pedesaan terhadap panen yang beresiko gagal karena musim kemarau melalui diversifikasi kegiatan yang dapat menghasilkan pendapatan (World Bank, 2000). Bank Indonesia sudah meluncurkan program akses financial inclucion tahun 2010 untuk mengentaskan kemiskinan dan mendorong pertumbuhan ekonomi (Soetanto dan Joko, 2012).

Salah satu model LKM yang berkembang relatif di Indonesia adalah Lembaga Keuangan Mikro Syariah (LKMS) prinsipnya hampir sama dengan LKM konvensional. Namun terdapat beberapa perbedaan dalam hal akad dan transaksi yakni persepsi yang tidak memperkenankan adanya bunga bank dan boleh bagi hasil dalam Islam yang mempengaruhi masyarakat menggunakan jasa bank syariah (Rahmayanty, 2014). Kegiatan LKMS meliputi jual beli, simpanan wadiah, mudharabah, musyarakah, zakat dan jasa lainnya (Hertanto, 1999). Baitul Maal wat Tamwil (BMT) berasal dari penggabungan lembaga baitul maal dan baitul tamwil.

Peran LKM mendukung fungsi intermediasi dengan UMKM sehingga BMT harus memiliki kinerja yang baik secara kelembagaan agar peran BMT sebagai lembaga pendukung intermediasi perbankan dapat tercapai dengan baik (Euis, 2009). Kenyataannya perkembangan BMT sejauh ini dipandang belum sepenuhnya mampu menjawab permasalahan ekonomi yang ada di kalangan masyarakat karena masalah rendahnya persepsi anggota, kurangnya kepercayaan masyarakat serta terbatasnya keikutsertaan pimpinan dan keanggotaan BMT dalam menyusun alokasi anggaran operasional (anggaran partisipatif) sehingga kepuasan kerja relatif rendah mengakibatkan rendahnya kinerja manajerial pimpinan BMT. Terdapat dua aspek yang yang sering dijadikan acuan dalam mengukur kinerja keuangan BMT yaitu keterjangkauan dan keberlanjutan. Keterjangkauan memberikan indikator bahwa layanan yang diberikan BMT berdasarkan jumlah nasabah dan kantor cabang. Keberlanjutan membuktikan bahwa BMT mampu bertahan dengan kemandirian dalam menghimpun dana masyarakat tanpa bergantung kepada lembaga donor asing atau proyek bantuan pemerintah yang sifatnya sesaat (hibah). BMT sebagai salah satu LKM harus memberikan pelayanan yang dilakukan secara terus menerus tanpa henti berdasarkan kepercayaan nasabah (Andyan, 2021).

Suitainabilitas BMT dapat dilihat dari aspek sustainabilitas lembaga dan suitainabilitas keuangan. Sustainabilitas lembaga adalah kemampuan BMT untuk beroperasi secara berkelanjutan didukung oleh faktor keberhasilan dalam mengimplementasikan cost effectiveness sebagai kunsi utama kegiatan usahanya 
Yenni Del Rosa dan Muhammad Abdilla, Pengaruh Persepsi Anggota, Kepercayaan Nasabah dan Anggaran Partisipatif terhadap Kinerja Manajerial Melalui Kepuasan Kerja Pada Baitul Maal Wat Tamwil "X" Kota Padang

sedangkan sustainabilitas keuangan merupakan kondisi keuangan BMT dalam kegiatannya dapat mencukupi kebutuhan biaya operasi dan biaya dana untuk jangka panjang. Terhambatnya perkembangan BMT menuju kemandirian karena kurangnya pengawasan terhadap laporan keuangan (Ridwan, 2013). Baitul Maal wat Tamwil sebagai LKMS hanya berbadan hukum koperasi berada di bawah Kementerian Negara Koperasi dan UMKM (Neni, 2010) sehingga pengawasannya sangat longgar bahkan dalam prakteknya otoritas Dinas Koperasi dan Usaha Mikro Kecil Menengah (UMKM) tidak banyak mengambil peran dalam pengawasan BMT (Ridwan, 2004).

Menurut (Ridwan, 1976) komersialisasi industri keuangan mikro menghadapi beberapa hambatan sebagai berikut : 1) Subsidi yang kurang tepat, 2) Buruknya regulasi dan pengawasan , 3) Jumlah tabungan yang dikumpulkan relatif sedikit, 4) Kapasitas manajemen terbatas, 5) Secara kelembagaan belum efisien, 6) Perlu penguasaan metode keuangan mikro yang lebih baik di pedesaan dan sektor pertanian. Kondisi ini menyebabkan sustainabilitas BMT maupun program keuangan mikro menjadi rendah. Hanya beberapa BMT yang mampu bertahan dan bersaing baik dengan sesama BMT maupun dengan jenis layanan perbankan yang lebih modern. Berdasarkan uraian di atas diatas masalah penelitian dapat dirumuskan sebagai berikut : Bagaimanakah pengaruh persepsi anggota, kepercayaan nasabah dan anggaran partisipatif terhadap kinerja manajerial melalui kepuasan kerja secara parsial dan simultan ? Tujuan penelitian untuk mengetahui pengaruh persepsi anggota, kepercayaan nasabah dan anggaran partisipatif terhadap kinerja manajerial melalui kepuasan kerja secara parsial dan simultan.

\section{Tinjauan Pustaka \\ Persepsi Anggota}

Harapan untuk meningkatkan partisipasi anggota hanya dapat terwujud bila anggota mempunyai persepsi positif terhadap kepemimpinan pengurus dalam mengelola dan mengembangkan usaha sesuai cita-cita dan tujuan bersama. Persepsi pada hakikatnya merupakan proses kognitif yang dialami oleh setiap orang dalam memahami informasi tentang lingkungan melalui penginderaan. Setiap orang mempunyai persepsi berbeda terhadap stimulus yang sama karena diterimanaya objek rangsangan melalui penginderaan oleh masing-masing individu yang selalu menanggapi, mengorganisasikan dan menafsirkan informasi sensorisnya menurut cara masing-masing individu. Menurut (Handayani, 2002) hal yang mempengaruhi persepsi adalah objek atau peristiwa yang dipahami, lingkungan yang terjadi dan orang yang melakukannya.

Persepsi merupakan proses bagaimana seseorang menyeleksi, mengatur dan menginterpretasikan masukan-masukan informasi untuk menciptakan gambaran keseluruhan yang berarti (Kotler dan Keller,
2012). Bila seseorang memandang pada suatu objek dan mencoba menafsirkan apa yang dilihatnya, penafsiran tersebut sangat dipengaruhi oleh karakteristik pribadi. Diantara karakteristik pribadi yang mempengaruhi persepsi seperti sikap, kepentingan (minat), motif, pengalaman masa lalu dan harapan (ekspektasi).

\section{Kepercayaan Nasabah}

Kepercayaan menjadi aspek penting bagi sebuah komitmen atau janji sehingga komitmen dapat direalisasikan. Kepercayaan merupakan faktor penting dapat mengatasi kritis dan kesulitan antara rekan bisnis sebagai asset penting dalam mengembangkan hubungan jangka panjang antar organisasi. Kepercayaan merupakan kesediaan seseorang untuk menggantungkan dirinya pada pihak lain dengan resiko tertentu. Kepercayaan adalah wilayah psikologis yang merupakan perhatian untuk menerima apa adanya berdasarkan harapan terhadap perilaku yang baik dari orang lain dan kepercayaan dibangun antara pihak-pihak yang belum saling mengenal dalam interaksi dan proses transaksi (Mc Knight, 2002).

Kepercayaan nasabah adalah keyakinan nasabah bahwa lembaga keuangan syariah akan memberikan sesuai dengan apa yang dijanjikan lembaga tersebut sesuai harapannya. Kepercayaan merupakan keyakinan satu pihak pada reliabelitas, durabilitas dan integritas pihak lain dalam relationship dan keyakinan bahwa tindakannya merupakan kepentingan paling baik dan akan menghasilkan hasil positif bagi pihak yang dipercaya. Kepercayaan pada sektor jasa keuangan syariah sangat penting sebagai katalis dalam transaksi lembaga keuangan syariah dengan nasabah sebagai konsumen agar kepuasan nasabah tercapai sesuai dengan yang diharapkan. Menurut (Mc Knight, 2002) indikator kepercayaan sbb : 1) Kejujuran, ,2) Kompetensi, 3) Informasi yang valid, 4) Jaminan kepuasan

\section{Kepuasan Kerja}

Seorang karyawan akan merasa nyaman dan tinggi loyalitasnya pada perusahaan jika memperoleh kepuasan kerja sesuai dengan yang diinginkannya. Meurut Luthan (2012) kepuasan kerja adalah suatu keadaan emosional yang dihasilkan dari persepsi terhadap suatu pekerjaan karena pekerjaan tersebut memenuhi atau mengikuti pemenuhan nilai kerja yang dimiliki seseorang dan sesuai dengan kebutuhan individu. Kepuasan kerja adalah keadaan emosional yang menyenangkan atau tidak menyenangkan bagaimana para karyawan memandang pekerjaan mereka (Handoko, 2000). Selanjutnya (Luthan, 2012) menyatakan bahwa kepuasan kerja adalah hasil dari persepsi karyawan mengenai seberapa baik pekerjaan mereka memberikan hal yang dinilai penting. Pendapat (Tiffin, 2012) kepuasan kerja berhubungan erat dengan sikap karyawan terhadap pekerjaannya sendiri, situasi kerja dan kerjasama antara pimpinan dengan sesama karyawan. Kemudian 
Yenni Del Rosa dan Muhammad Abdilla, Pengaruh Persepsi Anggota, Kepercayaan Nasabah dan Anggaran Partisipatif terhadap Kinerja Manajerial Melalui Kepuasan Kerja Pada Baitul Maal Wat Tamwil "X" Kota Padang

(Hasibuan, 2014) mendefinisikan kepuasan kerja sebagai bentuk sikap emosional yang menyenangkan dan tidak menyenangkan. Kepuasan kerja dapat dinikmati dalam pekerjaan, luar pekerjaan dan kombinasi dari dalam dan luar pekerjaan. Kepuasan kerja adalah sikap umum seorang individu terhadap pekerjaannya. Pekerjaan menuntut interaksi dengan rekan sekerja dan atasan, mengikuti aturan dan kebijakan organisasi, memenuhi standar kinerja, hidup pada kondisi yang sering kurang ideal dan hal serupa lainnya.

Berdasarkan definisi di atas dapat disimpulkan bahwa kepuasan kerja pada dasarnya merupakan tanggapan emosional terhadap situasi kerja. Setiap individu akan memiliki kepuasan kerja yang berbedabeda sehingga dalam pencapaian kepuasan kerja individu dituntut untuk mampu berinteraksi dengan rekan kerja, atasan dan mematuhi aturan yang berlaku dalam perusahaan. Indikator kepuasan kerja menurut (Mas'ud, 2004) sebagai berikut : 1) Gaji yang diterima, 2) Kemandirian pada pekerjaan, 3) Kerja sama seprofesi, 4) Komunikasi dengan atasan, 5) Kerja sama dengan atasan, 6) Kebanggaan dengan jabatan, 7) Kebijakan institusi, 8) Ketentuan pekerjaan saat ini.

\section{Anggaran Partisipatif}

Menurut (Supriyono, 2005) anggaran partisipatif adalah proses penyusunan anggaran yang melibatkan setiap manajer pusat pertanggungjawaban dan mereka memiliki kesempatan untuk menjelaskan dan memberikan alasan atas anggaran yang diusulkan. Partisipasi anggaran didefinisikan sebagai proses dimana kinerja individu akan dievaluasi, diberikan penghargaan atau hukuman berdasarkan tingkat pencapaian target anggaran (Chong \& Ming Cong, 2002). Partisipasi penyusunan anggaran diharapkan dapat meningkatkan kinerja manajerial yakni saat tujuan telah direncanakan dan disetujui secara partisipatif dan karyawan akan menginternalisasi tujuan tersebut serta bertanggung jawab secara personal untuk mencapainya melalui keterlibatan anggaran dalam proses anggaran (Cong \& Ming Cong, 2002). Partisipasi umumnya dinilai sebagai pendekatan manajerial yang dapat meningkatkan kinerja sehingga partisipasi anggaran berpengaruh terhadap kinerja manjerial. Partisipasi anggaran membuat manajer memiliki kesempatan untuk berinteraksi, berkomunikasi dan memberikan pengaruh terhadap tujuan atau sasaran yang akan dicapai sehingga akan menimbulkan respek manajer terhadap pekerjaan perusahaan. Anggaran partisipatif harus dilakukan secara komprehensif dan parsial (Gunawan dan Marwan, 2004). Menurut (Brownell, 1982) indikator anggaran partisipatif sebagai berikut: 1) Terlibat dalam penyusunan, 2) Terlibat dalam revisi, 3) Memberikan pendapat.

\section{Kinerja Manajerial}

Teori perusahaan merupakan konsep dasar dalam studi ekonomi manajerial. Perusahaan bisnis adalah kombinasi antara orang, aset fisik dan keuangan serta sistem dan informasi. Menurut (Agustini, 2018) penerapan ekonomi manajerial dapat menghasilkam hal sebagai berikut : 1) Membantu para manajer mengenal dan melakukan identifikasi terhadap kekuatan dan kelemahan ekonomi yang bisa mempengaruhi perusahaan, 2) Menetapkan kebijakan keputusan yang sesuai dengan standar operasional perusahaan. Kinerja manajerial merupakan salah satu faktor yang dapat meningkatkan efektifitas sebuah organisasi. Kinerja manajerial yaitu ukuran seberapa efisien dan efektif seorang manajer bisa menetapkan dan mencapai tujuan yang memadai (Stonner, 1996). Seseorang yang memegang posisi manajerial diharapkan mampu menghasilkan yang tinggi sedangkan kinerja karyawan umumnya bersifat konkrit, bersifat abstrak dan kompleks. Kinerja diartikan sebagai penentuan secara periodic efektifitas operasional suatu perusahaan, bagian dari perusahaan dan karyawan berdasarkan sasaran, standar dan kriteria yang telah ditetapkan sebelumnya. Dari definisi di atas dapat diambil kesimpulan bahwa kinerja manajerial adalah prestasi yang dicapai oleh perusahaan / organisasi melalui serangkaian proses atau kerangka kerja yang melibatkan suatu kelompok orangorang sebagai kesatuan bisnis untuk mencapai tujuan selama periode tertentu. Menurut (Suwardjono, 2010) pengukuran kinerja manajerial mempunyai tingkat saling ketergantungan tinggi. Kinerja manajer berdasarkan kepada kemampuan manajer dalam melaksanakan tugas manajerial berdasarkan indikator kinerja manajerial menurut (Mahoney, 1963) sebagai berikut : 1) Perencanaan, 2) Investigasi, 3) Pengkoordinasian, 4) Pengawasan, 5) Penilaian staf, 6) Negosiasi, 7) Perwakilan, 8) Kinerja keseluruhan, 9) Evaluasi, 10) Kinerja sesuai target.

\section{METODE}

Metode penelitian bersifat kuantitatif expost facto yaitu penelitian dilakukan untuk meneliti peristiwa yang telah terjadi kemudian merujuk ke belakang melalui fenomena data untuk menentukan faktor-faktor yang mendahului atau menentukan sebab-sebab yang mungkin atas peristiwa yang diteliti (Sugiyono, 2009).

Populasi adalah wilayah generalisasi yang terdiri atas subjek / objek yang mempunyai kualitas dan karakteristik tertentu diterapkan oleh peneliti untuk dipelajari kemudian ditarik kesimpulan (Sugiyono, 2009). Populasi dan sampel penelitian sebanyak 25 orang diambil secara total sampling atau sensus (Uma, 2006). Jenis data yang digunakan berupa data primer dikumpulkan dengan menggunakan angket dan data sekunder diambil dari library research berhubungan dengan berbagai teori sesuai variable penelitian. Instrumen penelitian terdiri dari variabel moderating kepuasan kerja (Y1), variabel terikat (Y2) kinerja manjerial dan variabel bebas persepsi anggota (X1), 
Yenni Del Rosa dan Muhammad Abdilla, Pengaruh Persepsi Anggota, Kepercayaan Nasabah dan Anggaran Partisipatif terhadap Kinerja Manajerial Melalui Kepuasan Kerja Pada Baitul Maal Wat Tamwil “ $X$ ” Kota Padang

kepercayaan nasabah (X2), anggaran partisipatif (X3) ditentukan sesuai dengan masing-masing indikatornya.

Teknik pengumpulan data menggunakan field research dan library research dengan melakukan survei dan observasi di BMT "X" Kota Padang serta sumbersumber lain terkait dengan variabel penelitian. Angket berisi daftar pernyataan dilengkapi dengan alternatif jawaban sebagai penjabaran dari indikator variabel terikat, variabel bebas dan variabel moderating menggunakan skala Likert skor $1-5$ sebagai berikut: SS = Sangat Setuju, $\mathrm{S}=$ Setuju, KS = Kurang Setuju, TS = Tidak Setuju dan STS = Sangat Tidak Setuju.

Teknik analisis data menggunakan SEM (Structural Equation Model) merupakan teknik modeling statistik bersifat cross sectional atau SEM merupakan teknik yang digunakan untuk membangun dan menguji model statistik dalam bentuk model sebab akibat atau path analysis (Abdillah dan Jogiyanto, 2015). Analisis jalur merupakan perluasan dari model regresi yang digunakan untuk menguji matriks korelasi pada model kausal yang dibandingkan oleh peneliti (Ghozali dan Fuad, 2005). Analisis jalur dikembangkan sebagai metode untuk mempelajari pengaruh (efek) secara lansung dan tidak lansung dari variabel bebas terhadap variabel tergantung.

Model SEM menjelaskan hubungan kelima variabel penelitian yang terbangun atas satu persamaan dan didalamnya terdapat satu variabel endogen. Kemudian dilakukan analisis multivariate menggunakan program SPSS (Ghozali, 2013). Hipotesis penelitian diuji pada tingkat signifikansi $5 \%$.

\section{HASIL DAN PEMBAHASAN}

Hasil penelitian menunjukkan bahwa kontribusi persepsi anggota, kepercayaan nasabah, anggaran partisipatif dan kepuasan kerja menjelaskan keragaman kinerja manajerial sebesar $46,7 \%$ sedangkan sisanya $53,3 \%$ dijelaskan oleh faktor lain yang tidak termasuk ke dalam model penelitian. Hubungan semua variabel endogen dengan kinerja manajerial tergolong kuat sebesar $85,3 \%$.
Nilai koefisien jalur persepsi anggota terhadap kinerja manajerial $(0.343 ; \mathrm{p}=0.000)$ artinya persepsi anggota berpengaruh positif signifikan terhadap kinerja manajerial (kinerja manajerial dijelaskan secara langsung oleh persepsi anggota). Nilai koefisien jalur kepercayaan nasabah terhadap kinerja manjerial $(0.149$; $\mathrm{p}=0.016)$ artinya kepercayaan nasabah berpengaruh positif signifikan terhadap kinerja manajerial (kinerja manajerial dijelaskan secara langsung oleh kepercayaan nasabah). Nilai koefisien jalur anggaran partisipatif terhadap kinerja manajerial $(0.327 ; \mathrm{p}=0.004)$ artinya anggaran partisipatif berpengaruh positif signifikan terhadap kinerja manajerial (kinerja manajerial dijelaskan secara langsung oleh anggaran partisipatif). Hal ini sejalan dengan hasil penelitian (Huseno, 2007) bahwa anggaran partisipatif berpengaruh positif signifikan terhadap kinerja manajerial di nilai koefisien jalur kepuasan kerja terhadap kinerja manajerial (0.205; $\mathrm{p}=0.000)$ artinya kepuasan kerja berpengaruh positif signifikan terhadap kinerja manajerial. Hal ini sejalan dengan hasil penelitian (Huseno, 2017) bahwa kepuasan kerja berpengaruh positif signifikan terhadap kinerja manajerial di ??? Ketiga faktor penentu kinerja manajerial, kontribusi terbesar berasal dari persepsi anggota sebesar 0.343 .

Pembuktian variabel pemoderasi hubungan kepuasan kerja dengan kinerja manajerial dibuktikan melalui hasil uji koefisien interaksi. Nilai koefisien jalur interaksi persepsi anggota dengan kinerja manajerial signifikan karena $(0.209 ; \mathrm{p}=0.005)$ uji ini membuktikan bahwa persepsi anggota memoderasi hubungan kepuasan kerja dengan kinerja manajerial. Nilai koefisien jalur interaksi kepercayaan nasabah dengan kinerja manajerial tidak signifikan karena $(0.007 ; \mathrm{p}=0.150)$ uji ini membuktikan bahwa kepercayaan nasabah tidak memoderasi hubungan kepuasan kerja dengan kinerja manajerial. Nilai koefisien jalur anggaran partisipatif dengan kinerja manajerial tidak signifikan karena ($0.081 ; \mathrm{p}=0.150)$ uji ini membuktikan bahwa anggaran partisipatif tidak memoderasi hubungan kepuasan kerja dengan kinerja manajerial. Hasil uji koefisien inner model dapat dilihat pada tabel 1 berikut:

Tabel 1. Hasil Uji Koefisien Inner Model

\begin{tabular}{|c|c|c|c|c|}
\hline Hubungan Variabel & Original Sample & Standard Error & $\mathbf{t}$ & Prob. \\
\hline \multicolumn{5}{|l|}{ Endogen : Kinerja Manajerial $(K M), \mathbf{R}^{2}=85.3 \%$} \\
\hline Persepsi Anggota $\rightarrow$ Kinerja Manajerial & 0.343 & 0.075 & 4.525 & 0.000 \\
\hline Kepercayaan Nasabah $\rightarrow$ Kinerja Manajerial & 0.149 & 0.067 & 2.464 & 0.016 \\
\hline Anggaran Partisipatif $\rightarrow$ Kinerja Manajerial & 0.327 & 0.108 & 2.965 & 0.004 \\
\hline Kepuasan Kerja $\rightarrow$ Kinerja Manajerial & 0.205 & 0.062 & 4.699 & 0.000 \\
\hline Persepsi Anggota x Kepuasan Kerja $\rightarrow$ Kinerja Manajerial & 0.209 & 0.079 & 2.802 & 0.005 \\
\hline Anggaran Partisipatif x Kepuasan Kerja $\rightarrow$ Kinerja Manajerial & -0.081 & 0.071 & 1.151 & 0.250 \\
\hline Kepercayaan Nasabah x Kepuasan Kerja $\rightarrow$ Kinerja Manajerial & 0.007 & 0.069 & 0.101 & 0.870 \\
\hline
\end{tabular}

Sumber: Hasil Olahan Data PLS (2021) 
Yenni Del Rosa dan Muhammad Abdilla, Pengaruh Persepsi Anggota, Kepercayaan Nasabah dan Anggaran Partisipatif terhadap Kinerja Manajerial Melalui Kepuasan Kerja Pada Baitul Maal Wat Tamwil “X” Kota Padang

\section{Outer Model}

Outer model bertujuan menguji hubungan masingmasing indikator terhadap konstruk laten yang ada dalam inner model. Hubungan indikator dengan konstruk laten bersifat reflektif dan bobot faktor akan diambil dari nilai loading factor. Indikator nilai loading factor paling besar menerangkan bahwa konstruk laten paling kuat membentuk indikator tersebut. Indikator dengan nilai loading factor 0.50 menunjukkan bahwa indikator tersebut memiliki validasi baik untuk mengukur variabel laten.

Anggaran partisipatif secara substantif lebih banyak terukur pada indikator intensitas atasan dalam meminta pendapat bawahan (AP6) untuk kinerja manajerial dengan nilai loading factor 0.837. Tingkat kehandalan keenam indikator nilai AVE 0.587 composite reliability 0.893 dan koefisien alpha cronbach 0.857. Pada konstruk anggaran partisipatif indikator utamanya seberapa sering atasan BMT " $X$ " Kota Padang meminta pendapat bawahannya. Persepsi anggota secara substantif lebih banyak terukur pada indikator mengacu pada fatwa syariah (PA8) untuk kinerja manajerial dengan nilai loading factor 0.871 . Tingkat kehandalan kesepuluh indikator nilai AVE 0.536 composite reliability 0.917 dan koefisien alpha cronbach 0.879. Pada konstruk persepsi anggota indikator utamanya mengacu pada fatwa syariah yang melekat pada BMT "X" Kota Padang. Kepercayaan nasabah secara substantif lebih banyak terukur pada indikator kejujuran (KN1) untuk kinerja manajerial dengan nilai loading factor 0.908. Tingkat kehandalan keempat indikator nilai AVE 0,681 composite reliability 0.893 dan koefisien alpha cronbach 0.846. Pada konstruk kepercayaan nasabah indikator utamanya kejujuran pada BMT "X" Kota Padang. Kepuasan kerja secara substantif lebih banyak terukur pada indikator kebanggaan dengan jabatan (KK6) dengan nilai loading factor 0.869. Tingkat kehandalan kedelapan indikator nilai AVE 0.577 composite reliability 0.921 dan koefisien alpha cronbach 0.879 . Pada konstruk kepuasan kerja indikator utamanya karyawan BMT " $X$ " Kota Padang merasa bangga dengan jabatan yang diberikan oleh atasannya. Kinerja manajerial secara substantif lebih banyak terukur pada indikator penilaian staf (KM5). Indikator ini mempunyai nilai loading factor 0.823. Tingkat kehandalan seluruh indikator nilai AVE 0.566 composite reliability 0.951 dan koefisien alpha cronbach 0.927. Pada konstruk kinerja manajerial indikator utamanya penilaian staf. Dalam hal ini pimpinan BMT "X" Kota Padang dapat menilai kemampuan stafnya dengan menyeleksi, mempertahankan dan mempromosikan jabatan kepada bawahannya secara tepat. Untuk lebih jelasnya outer model penelitian dapat dilihat pada tabel 2 berikut.

Tabel 2. Outer Model

\begin{tabular}{|c|c|c|c|c|}
\hline Indikator & $\begin{array}{c}\text { Loading } \\
\text { Factor }\end{array}$ & AVE & $\begin{array}{l}\text { Composite } \\
\text { Reliability }\end{array}$ & $\begin{array}{c}\text { Alpha } \\
\text { Cronbach } \\
\end{array}$ \\
\hline Anggaran Partisipatif (AP) & & 0.587 & 0.893 & 0.857 \\
\hline Terlibat dalam penyusunan (AP1) & 0.707 & & & \\
\hline Terlibat dalam revisi (AP2) & 0.729 & & & \\
\hline Memberikan pendapat (AP3) & 0.761 & & & \\
\hline Usulan anggaran (AP4) & 0.809 & & & \\
\hline Usulan dari bawahan (AP5) & 0.728 & & & \\
\hline Pendapat bawahan (AP6) & 0.837 & & & \\
\hline Persepsi Anggota (PA) & & 0.536 & 0.917 & 0.879 \\
\hline Bebas riba (PA1) & 0.678 & & & \\
\hline Menjalankan baitul maal (PA2) & 0.762 & & & \\
\hline Menjauhi haram (PA3) & 0.672 & & & \\
\hline Menjauhi maysir dan gharar (PA4) & 0.757 & & & \\
\hline Saling menguntungkan (PA5) & 0.759 & & & \\
\hline Halal dan tayyib (PA6) & 0.748 & & & \\
\hline Tidak mudharat (PA7) & 0.757 & & & \\
\hline Mengacu pada fatwa syariah (PA8) & 0.871 & & & \\
\hline Pembagian resiko (PA9) & 0.665 & & & \\
\hline Larangan spekulatif (PA10) & 0.673 & & & \\
\hline Kepercayaan Nasabah (KN) & & 0.681 & 0.893 & 0.846 \\
\hline Kejujuran (KN1) & 0.908 & & & \\
\hline Kompetensi (KN2) & 0.757 & & & \\
\hline Informasi yang valid (KN3) & 0.743 & & & \\
\hline Jaminan kepuasan (KN4) & 0.875 & & & \\
\hline Kepuasan Kerja (KK) & & 0.577 & 0.921 & 0.879 \\
\hline Gaji yang diterima (KK1) & 0.812 & & & \\
\hline
\end{tabular}


Yenni Del Rosa dan Muhammad Abdilla, Pengaruh Persepsi Anggota, Kepercayaan Nasabah dan Anggaran Partisipatif terhadap Kinerja Manajerial Melalui Kepuasan Kerja Pada Baitul Maal Wat Tamwil “ $X$ ” Kota Padang

Kemandirian pada pekerjaan (KK2)

Kerjasama seprofesi (KK3)

Komunikasi dengan atasan (KK4)

Kerjasama dengan atasan (KK5)

Kebanggaan dengan jabatan (KK6)

Kebijakan institusi (KK7)

Ketentuan pekerjaan saat ini (KK8)

Kinerja Manajerial (KM)

Perencaaan (KM1)

Investigasi (KM2)

Pengkordinasian (KM3)

Pengawasan (KM4)

Penilaian staf (KM5)

Negosiasi (KM6)

Perwakilan (KM7)

Kinerja keseluruhan (KM8)

Evaluasi (KM9)

Kinerja sesuai target (KM10)
0.678

0.747

0.725

0.736

0.869

0.719

0.757

0.669

0.687

0.648

0.823

0.809

0.787

0.817

0.795

0.762

Sumber: Hasil Olahan Data PLS (2021)

Inner model dalam penelitian ini hanya mempunyai satu variabel endogen yaitu kinerja manajerial. Ketepatan model diukur dari nilai $\mathrm{R}^{2}$ dan $\mathrm{F}^{2}$. Nilai $\mathrm{R}^{2}$ pada model sebesar $86.4 \%$ menjelaskan tingginya kecocokan model hubungan persepsi anggota, kepercayaan nasabah, anggaran partisipatif dan kepuasan kerja dengan kinerja manajerial. Nilai $\mathrm{F}^{2}$ mengukur efek yang ditimbulkan jika jalur yang menghubungkannya dengan kinerja manajerial dihilangkan dari model. Nilai $\mathrm{F}^{2}$ menjelaskan rasio perubahan $\mathrm{R}^{2}$ setelah satu jalur dihilangkan dalam model. Nilai $\mathrm{F}^{2}$ sebesar 0.15 menerangkan bahwa jalur tersebut tidak memberikan efek yang besar sebagai penjelas kinerja manajerial seperti pada tabel 3 berikut.

Tabel 3. Hasil Perhitungan Nilai $\mathbf{F}^{2}$

\begin{tabular}{lc}
\hline \multicolumn{1}{c}{ Hubungan Variabel } & $\mathbf{F}^{\mathbf{2}}$ \\
\hline Persepsi Anggota $\rightarrow$ Kinerja Manajerial & 0.359 \\
Kepercayaan Nasabah $\rightarrow$ Kinerja Manajerial & 0.096 \\
Anggaran Partisipatif $\rightarrow$ Kinerja Manajerial & 0.177 \\
Kepuasan Kerja $\rightarrow$ Kinerja Manajerial & 0.358 \\
Persepsi Anggota x Kepuasan Kerja $\rightarrow$ Kinerja Manajerial & 0.034 \\
Anggaran Partisipatif x Kepercayaan Nasabah $\rightarrow$ Kinerja Manajerial & 0.000 \\
Anggaran Partisipatif x Kepuasan Kerja $\rightarrow$ Kinerja Manajerial & 0.167 \\
\hline
\end{tabular}

Sumber: Hasil Olahan Data PLS (2021)

Berdasarkan tabel 3 di atas diperoleh nilai $\mathrm{F}^{2}$ beberapa diantaranya kurang dari 0.15 seperti kepercayaan nasabah, persepsi anggota dan anggaran partisipatif, berarti jalur hubungan kepercayaan nasabah dengan kinerja manajerial, jalur interaksi anggaran partisipatif dan kepercayaan nasabah terhadap kinerja manajerial serta jalur interaksi anggaran partisipatif dan kepuasan kerja terhadap kinerja manajerial tergolong rendah.

\section{SIMPULAN}

berikut:

Hasil penelitian dapat disimpulkan sebagai

1. Terdapat hubungan signifikan antara kinerja manajerial dengan persepsi anggota, kepercayaan nasabah dan anggaran partisipatif melalui kepuasan kerja pada BMT "X" kota Padang.
2. Persepsi anggota memoderasi hubungan kepuasan kerja dengan kinerja manajerial artinya kepuasan kerja yang dirasakan para pegawai berpengaruh sebagai pemoderasi terhadap kinerja manajerial BMT "X" Kota Padang.

3. Kepercayaan nasabah tidak memoderasi hubungan kepuasan kerja dengan kinerja manajerial artinya kepuasan kerja yang dirasakan para pegawai tidak berpengaruh sebagai pemoderasi terhadap kinerja manajerial pada BMT " $X$ " kota Padang

4. Anggaran partisipatif tidak memoderasi hubungan kepuasan kerja dengan kinerja manajerial artinya kepuasan kerja yang dirasakan pegawai tidak berpengaruh sebagai pemoderasi terhadap kinerja manajerial BMT "X" kota Padang. 
Yenni Del Rosa dan Muhammad Abdilla, Pengaruh Persepsi Anggota, Kepercayaan Nasabah dan Anggaran Partisipatif terhadap Kinerja Manajerial Melalui Kepuasan Kerja Pada Baitul Maal Wat Tamwil “X” Kota Padang

\section{DAFTAR PUSTAKA}

Abdillah, W dan Jogiyanto. 2015. Partial Least Square (PLS) Alternatif Structural Equation Modelling (SEM) Dalam Penelitian Bisnis. Yogyakarta: Penerbit Andi.

Adisaputo, Gunawan dan Marwan Asri. 2004. Anggaran Perusahaan Buku 1 Edisi 2003/2004. Yogyakarta : BPFE.

Agustini, Maria Y.D. Hayu. 2018. Ekonomi Manajerial Pembuatan Keputusan Berdasar Teori Ekonomi. Semarang : Universitas Katolik Soegijapranata.

Brownell, P. 1982. Afield Study Examination of Budgetary Participation and Locus of Control. Accounting Review.Vol LVII (4).

Buchori, Achmad. 2003. Kajian Kinerja Industri BPRS Di Indonesia. Buletin Ekonomi Moneter dan Perbankan. Volume 5(4).

Chong, Vincent K. dan Kar Ming Chong. 2002. Budget Goal Commitment and Informational Effects of Budget Participation on Performance: Astructural Equation Modeling Approach, Behavioral Research in Accounting, USA.

Euis Amaliah. 2009. Keadilan Distributif Dalam Ekonomi Islam, Perkuatan Peran LKM dan UMKM Di Indonesia. Jakarta: Raja Grafindo Persada.

Ghozali, Imam dan Fuad. 2005. Structural Equation Modelling : Teori, Konsep \& Aplikasi. Semarang : Penerbit Universitas Diponegoro.

Ghozali, Imam. 2013. Aplikasi Analisis Multivariat dengan Program SPSS. Edisi 7. Semarang : Universitas Diponegoro.

Handoko, H.T. 2000. Manajemen Personalia dan Sumberdaya Manusia Edisi II. Cetakan Keempat Belas. Yogyakarta: BPFE.

Hasibuan, Melayu. 2014. Manajemen : Dasar, Pengetian dan Masalah. Edisi Revisi. Jakarta : Bumi Aksara.

Hertanto Widodo. 1999. Panduan Praktis Operasional Baitul Maal wa Tamwil. Bandung: Mizan.

Huseno, Tun. 2007. Pengaruh Kepemimpinan, Misi Organisasi dan Budaya Organisasi Terhadap Kepuasan Kerja dan Kinerja Perawat Rumah Sakit Tipe B Di Sumatera Barat. Disertasi. Fakultas Ilmu Administrasi Universitas Brawijaya Malang.

Huseno, Tun. 2017. Motivasi, Kepuasan Kerja dan Budaya Organisasi Pemoderasi Partisipasi Penyusunan Anggaran Terhadap Kinerja Manajerial (Studi Empiris Pada Pemerintah Kota Padang). Jurnal Ekonomi dan Bisnis Dharma Andalas. 19(2) : $315-322$.

Kotler, Philip dan Keller. 2012. Marketing Management. Jakarta: Rineka Cipta.

Luthan, Landy. 2012. Perilaku Organisasi. Edisi Bahasa Indonesia. Yogyakarta : Andi.

Mahoney, T.A. Jerdee \& S.J.Carroll. 1963. Development of Managerial Performance. A Research
Approach. Cincinnati. Ohio : South Western Publishing Co.

Mas'ud, Fuad. 2004. Survei Diagnosis Operasional, Konsep dan Aplikasi. Semarang: Badan Penerbit Universitas Diponegoro.

Mc Knight, D. 2002. Developing and Validating Trust Measure for E-Commerce: An Integrative Typology. Information System Research. Volume 13: $334-359$.

Neni Sri Imaniyati. 2010. Aspek Hukum Baitul Maal wat Tamwil. Bandung: Citra Aditya Bakti.

Rahmayanty, Anita. 2014. Pengaruh Persepsi Tentang Bank Syariah Terhadap Minat Menggunakan Produk BNI Syariah Semarang. Jurnal ADDIN. Volume 8(1) : 3 - 19.

Ridwan, Muhammad. 1976. Manajemen Baitul Maal wa Tamwil (BMT). Malang : Pustaka Hidayah.

Ridwan, Ahmad Hasan. 2004. BMT dan Bank Islam : Instrumen Lembaga Keuangan Syariah. Bandung : Pustaka Bani Quraisy.

Ridwan, Ahmad Hasan. 2013. Manajemen Baitul Maal wa Tamwil (BMT). Surakarta : Pustaka Setia.

Sekaran, Uma. 2006. Research Methods for Business. Jakarta : Salemba Empat.

Stonner, J.A.F, Freeman, R.E dan Gilbert. J.R. 1996. Strategic Management. New Jersey: PrenticeHall. Inc.

Sugiyono. 2009. Metode Penelitian Bisnis Pendekatan Kuantitatif, Kualitatif dan $R \& D$. Bandung: Alfabeta.

Supriyono, R.A. 2005. Pengaruh Komitmen Organisasi, Keinginan Sosial dan Asimetri Informasi Terhadap Hubungan Antara Partisipasi Anggaran dengan Kinerja Manajer. Jurnal Ekonomi dan Bisnis Indonesia. 2(1) : 3 - 19.

Soetanto, Hadinoto \& Joko Retnadi. 2012. Micro Credit Challenge: Cara Efektif Mengatasi Kemiskinan dan Pengangguran Di Indonesia. Jakarta: Elex Media Computindo.

Suwardjono. 2010. Teori Akuntansi Perekayasaan Pelaporan Keuangan. Edisi Ketiga. Cetakan Kelima. Yogyakarta : BPFE Yogyakarta.

Tiffin, Joseph. 2012. Psikologi Industri. Yogyakarta : Liberty.

Utama, Andyan Pradipta. 2021. Nasabah dan Bank. Analisis Faktor-Faktor yang Mempengaruhi Loyalitas Nasabah Pemegang Kartu Kredit Di Indonesia. Jakarta : Antarmedia.

World Bank. 2000. World Development Report 2000 / 2001. Washington D.C: The World Bank 2000. 